\title{
The stepwise evolution of fragment hits against MAPK Interacting Kinases 1 and 2
}

Jacek Kwiatkowski, Boping Liu, Shermaine Pang, Nur Huda Binte Ahmad, Gang Wang, Anders Poulsen, Haiyan Yang, Yong Rui Poh, Doris Hui Ying Tee, Esther Ong, Priya Retna, Nurul Dinie, Perlyn Kwek, John Liang Kuan Wee, Vithya Manoharan, Choon Bing Low, Peck Gee Seah, Vishal Pendharkar, Kanda Sangthongpitag, Joma Joy, Nithya Baburajendran, Anna Elisabet Jansson, Kassoum Nacro, Jeffrey Hill, Thomas H. Keller and Alvin W. Hung*

Experimental Drug Development Centre, Agency for Science, Technology and Research (A*STAR), 10 Biopolis Way, Chromos \#05-01/06, Singapore 138670

Correspondence and requests for materials should be addressed to whung@eddc.a-star.edu.com.sg

\section{Contents}

1. Inhibitory activity of additional compounds

2. In vitro and in vivo $\mathrm{PK}$ compilation and mouse $\mathrm{PK}$ for compounds $\mathrm{S} 2$ 44 and 48

3. Molecular Modelling and analysis of MNK isoforms similarity S5

4. X-ray crystal structure details $\quad$ S8

5. Chemistry: synthesis and characterization of additional S10 compounds

6. HPLC spectrograms for advanced compounds 


\section{Inhibitory activity of additional compounds}

SI Table 1. Biochemical potency of cyclic amide analogues of compound 36.

\begin{tabular}{|c|c|c|c|c|c|c|c|}
\hline \multirow{2}{*}{ Cmpd } & \multirow{2}{*}{ Structure } & \multicolumn{2}{|c|}{$\mathbf{I C}_{50}[\mu \mathrm{M}](\mathbf{L E})$} & \multirow{2}{*}{ Cmpd } & \multirow{2}{*}{ Structure } & \multicolumn{2}{|c|}{$\mathbf{I C}_{50}[\mu \mathrm{M}](\mathbf{L E})$} \\
\hline & & MNK2 & MNK1 & & & MNK2 & MNK1 \\
\hline 36 & & $0.35(0.42)$ & $0.8(0.40)$ & 51 & & $0.23(0.36)$ & $1.0(0.33)$ \\
\hline 50 & & $0.11(0.41)$ & $0.32(0.39)$ & 52 & & $0.097(0.37)$ & $0.21(0.35)$ \\
\hline
\end{tabular}

\section{In vitro and in vivo PK compilation and mouse PK for compounds 44 and 48}

Compounds were shortlisted for in vivo PK based on their potency and in vitro PK profile; compounds with high clearance in mouse liver microsome assay were not progressed to animal studies. 44 is a close analogue of compound $\mathbf{4 3}$, which in turn is considered the best in the series based on balanced PK and decent potency in biochemical and cellular assay. On the other hand, as shown in SI Table 2, clearance of 44 is 10 -fold higher reaching $37 \mu \mathrm{L} \cdot \mathrm{min}^{-1} \cdot \mathrm{mg}^{-1}$. As such it was expected that the in vivo exposure would be decreased as compared to 43 . Indeed, significantly lower AUC was observed for $\mathbf{4 4}\left(\mathrm{AUC}_{0 \text {-last }}=387 \mathrm{ng} \cdot \mathrm{h} \cdot \mathrm{ml}^{-1}\right)$, while $\mathrm{C}_{\max }$ for both compounds was similar (SI Table 2 and 3). Similarly, compound 48 showed decreased AUC, which corresponded to increased rate of clearance as compared to 43 ; however, 48 also had the lowest $\mathrm{C}_{\max }$ in the series, signifying poorer absorption. 
SI Table 2. In vitro and in vivo PK profiles compared for the 4 key compounds.
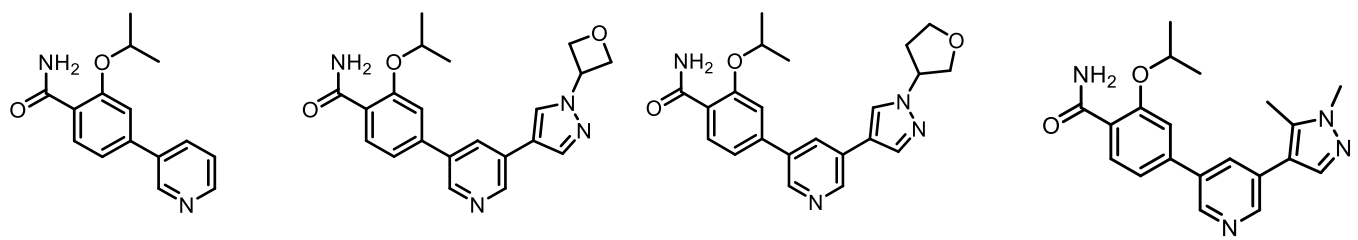

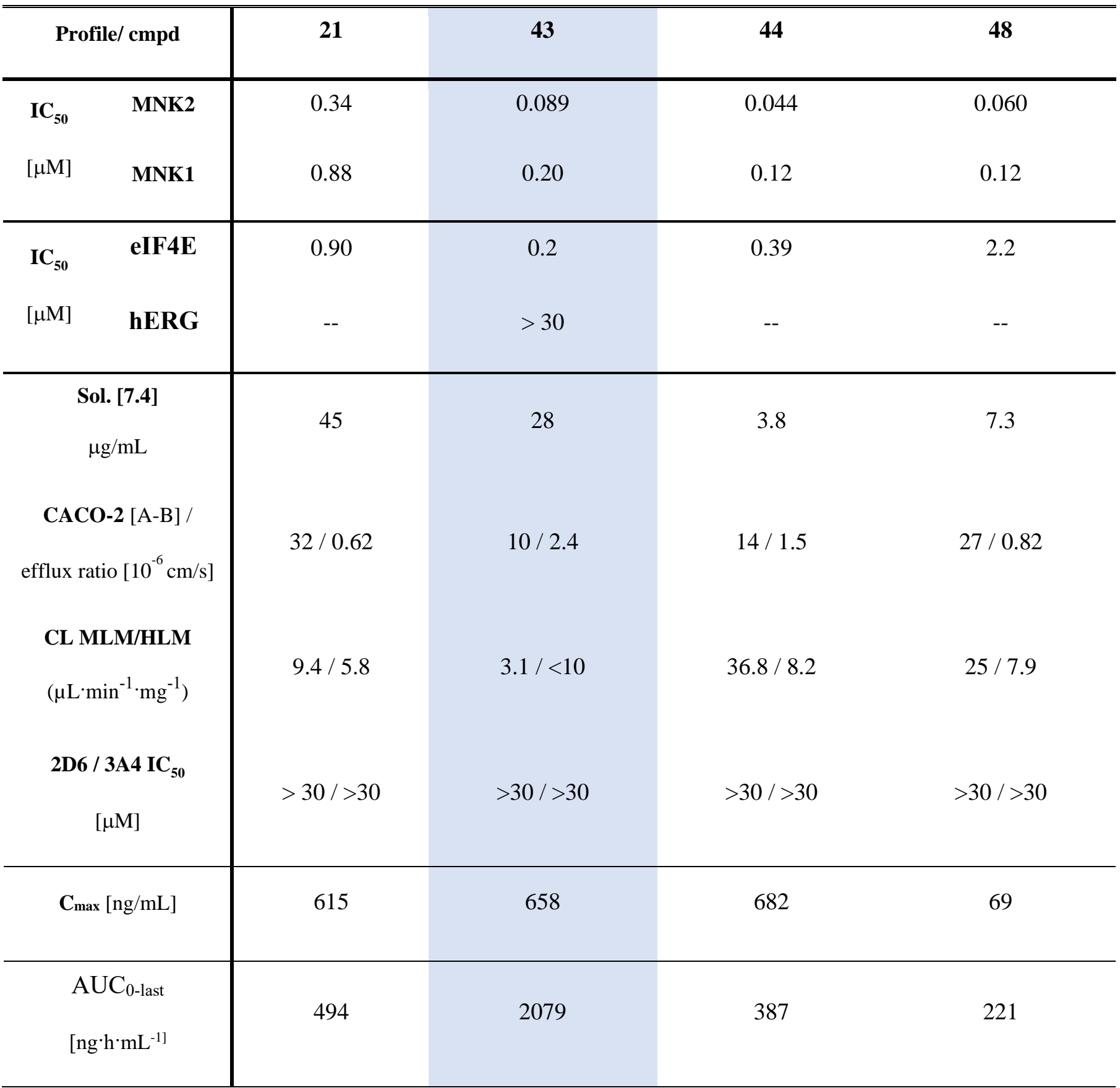




\section{Supporting Information}

SI Table 3. In vivo PK of compound 44. Higher rate of clearance of compound 44, as compared to 43 translated into lower AUC, despite similar $\mathrm{C}_{\max }$.

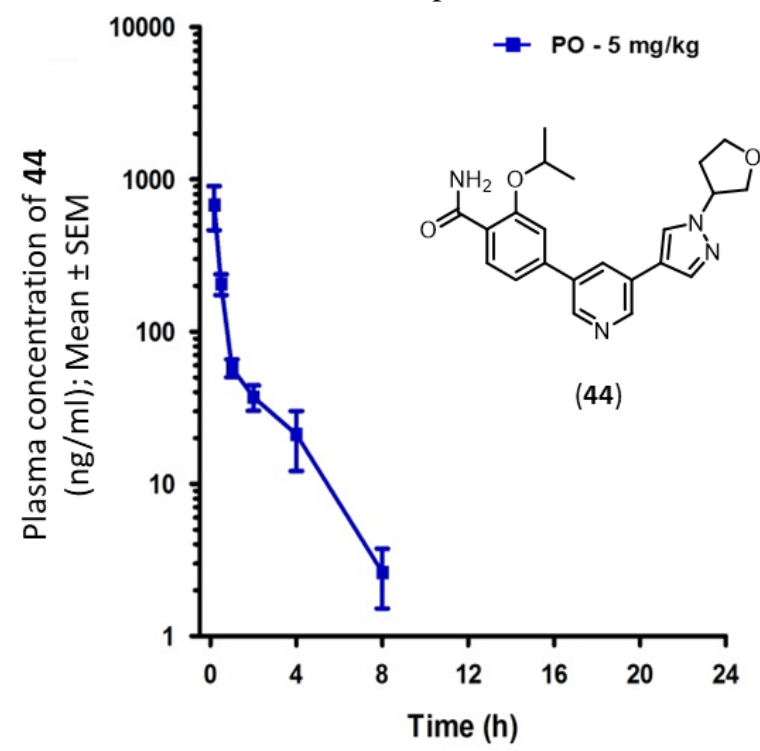

\begin{tabular}{|c|c|c|}
\hline Parameters & Unit & PO \\
\hline Dose & $\mathbf{m g} / \mathbf{k g}$ & $\mathbf{5}$ \\
\hline $\mathbf{C}_{\max }$ & $\mathrm{Ng} / \mathrm{ml}$ & 682 \\
\hline $\mathbf{T}_{\max }$ & $\mathrm{h}$ & 0.17 \\
\hline $\mathbf{T}_{1 / 2}$ & $\mathrm{~h}$ & 1.5 \\
\hline $\mathbf{C L} / \mathbf{F}$ & $\mathrm{L} \cdot \mathrm{h}^{-1} \cdot \mathrm{kg}^{-1}$ & 12.7 \\
\hline $\mathbf{V}_{\mathbf{z}}$ & $\mathrm{L} / \mathrm{kg}$ & 28 \\
\hline $\mathbf{A U C}_{\text {0-t(last) }}$ & $\mathrm{ng} \cdot \mathrm{h} \cdot \mathrm{mL}^{-1}$ & 387 \\
\hline $\mathbf{A U C}_{\text {0-inf }}$ & $\mathrm{ng} \cdot \mathrm{h} \cdot \mathrm{mL}^{-1}$ & 393 \\
\hline
\end{tabular}

SI Table 4. In vivo PK of compound 48. Decreased $\mathrm{C}_{\max }$ and $\mathrm{AUC}$ were observed for $\mathbf{4 8}$ indicating poor absorption.

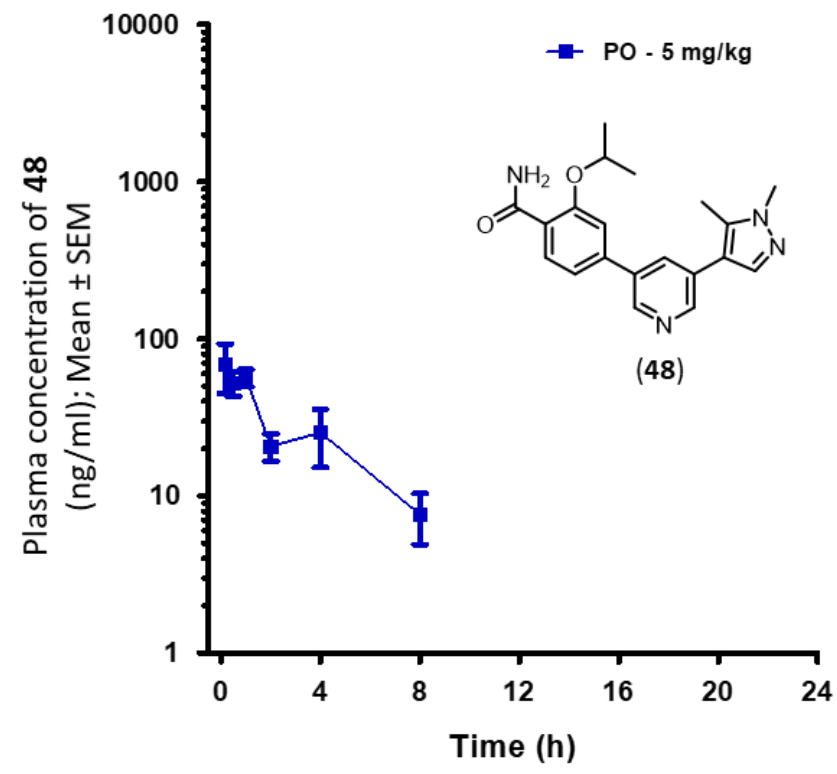

\begin{tabular}{|c|c|c|}
\hline Parameters & Unit & PO \\
\hline Dose & $\mathrm{mg} / \mathrm{kg}$ & $\mathbf{5}$ \\
\hline $\mathrm{C}_{\max }$ & $\mathrm{ng} / \mathrm{ml}$ & 69 \\
\hline $\mathrm{T}_{\max }$ & $\mathrm{h}$ & 0.17 \\
\hline $\mathrm{T}_{1 / 2}$ & $\mathrm{~h}$ & 2.7 \\
\hline $\mathrm{CL} / \mathbf{F}$ & $\mathrm{L} \cdot \mathrm{h}^{-1} \cdot \mathrm{kg}^{-1}$ & 22 \\
\hline $\mathbf{V}_{\mathbf{z}}$ & $\mathrm{L} / \mathrm{kg}^{-1}$ & 88 \\
\hline AUC $_{\text {0-t(last) }}$ & $\mathrm{ng} \cdot \mathrm{h} \cdot \mathrm{mL}^{-1}$ & 221 \\
\hline AUC $_{\text {0-inf }}$ & $\mathrm{ng} \cdot \mathrm{h} \cdot \mathrm{mL}^{-1}$ & 226 \\
\hline
\end{tabular}

\section{Molecular Modelling and analysis of MNK isoforms similarity}

The X-ray structure of MNK2 complexed with Staurosporine was downloaded from the protein data bank (www.rcsb.org, PDB code 2HW7). The structure was prepared using the protein preparation wizard in Maestro release 2017-3 (www.schrodinger.com) with standard settings. This included the addition of hydrogen atoms, bond assignments, removal of all water molecules, protonation state assignment and optimization of the hydrogen bond network. The missing atoms of residues Ile122 and Gly370 was added using Prime release 2017-3 
(www.schrodinger.com). Staurosporine was deleted from the prepared structure and the inhibitors were then manually docked into the ATP-site using Maestro. It was assumed that the amino-pyridine part of our compounds forms the same hydrogen bond with the kinase hinge residue Met162 as the acceptor in the adenine of ATP and that the phenyl interacts with the sidechain of the gatekeeper residue Phe159. The crystal water hydrogen bonding to residues Glu129 and Asp226 was kept as the inhibitor amine may interact with the water. Residues beyond $9 \AA$ of the inhibitor was constrained and the complex was then subjected to 500 steps of TNCG minimization using the OPLS3 force field and GB/SA solvation model implemented in MacroModel release 2017-3 (www.schrodinger.com). A map of the binding site was calculated for the minimized complex with compound 13 using SiteMap release 2017-3 (www.schrodinger.com).

\section{MNK1 \& MNK2 alignment}

In contrast to the majority of kinases that have a DFG-motif, both MNK kinases have a DFDmotif. Analysis of the published MNK X-ray structures revealed that MNK1 is crystalized in the DFD-out conformation only, while MNK2 is crystalized in the DFD-in conformation as well as a state in-between in and out. Apart from the conformational difference that may be a crystalization artefact, the binding-sites are very similar. There are no obvious residue differences in the binding-sites that may be targeted for achieving MNK subtype selectivity. The homology between MNK1 and MNK2 is $84 \%$ and the sequence identity is $73 \%$ (SI Figure 1).

SI Figure 1. Comparison of MNK1 and MNK2 structures; a) sequences of MNK1 and MNK2 with crystallized residues in bold font; b) alignment of MNK1 and MNK2 with colourcoded secondary structures and binding sites. 
Full Protein Sequences from Uniprot crystalized residues in black

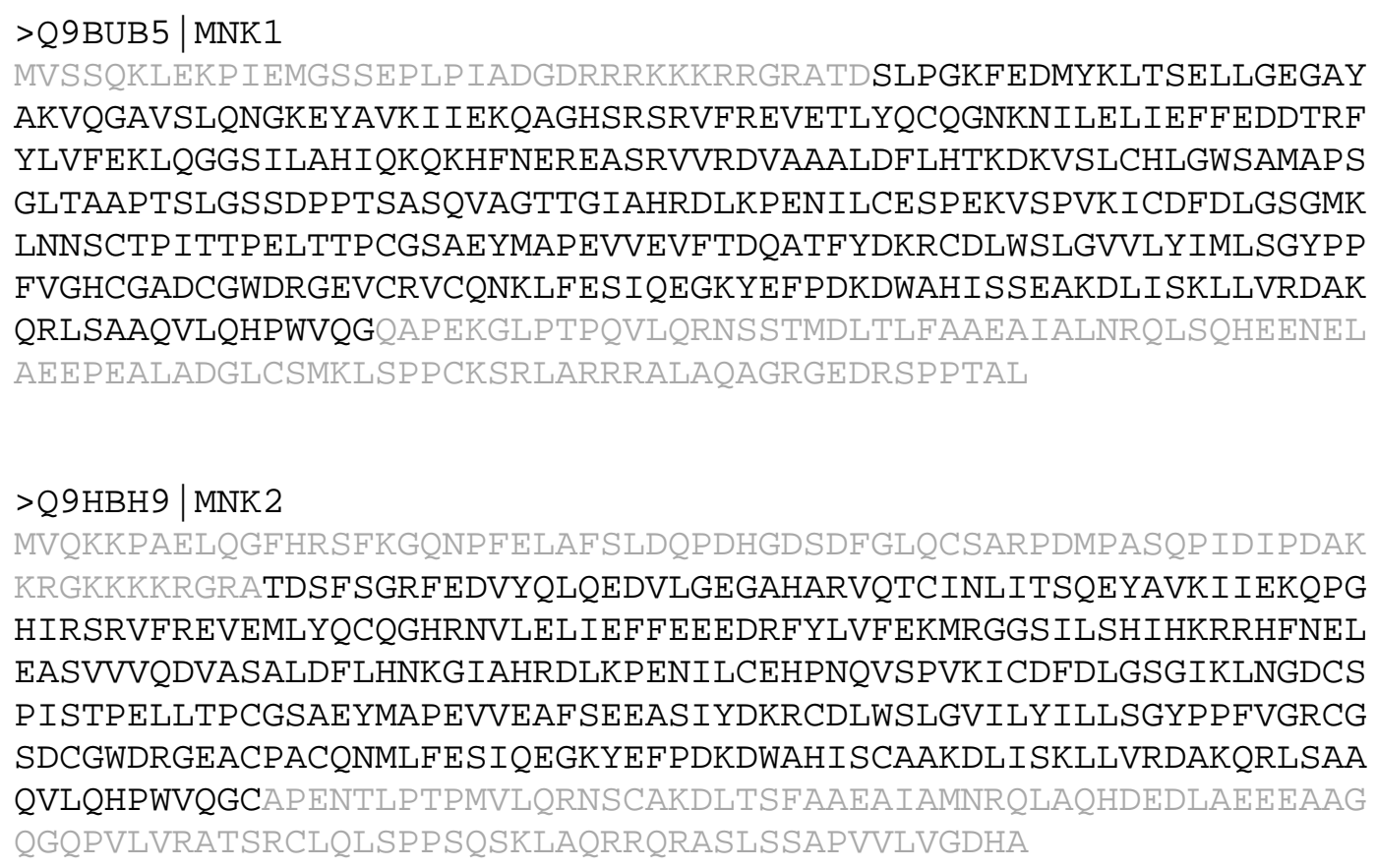




\section{CLUSTAL W (1.83) multiple sequence alignment of Mnk1 \& Mnk2}

Structural information from X-ray structures

Mnk1: $2 \mathrm{HW} 6$

Mnk2: 2AC3, 2AC5, 2HW7

crystalized residues in black

Binding Site
Binding Site \& Beta Strand
Binding Site \& Alpha Helix
Alpha Helix
Beta Strand

Q9BUB5 | MNK1 Q9HBH9|MNK2

Q9BUB5 | MNK1 Q9HBH9|MNK2

Q9BUB5 | MNK1 Q9HBH9|MNK2

Q9BUB5 | MNK1 Q9HBH9|MNK2

Q9BUB5 | MNK1 Q9HBH9|MNK2

Q9BUB5 | MNK1 Q9HBH9|MNK2

Q9BUB5 | MNK1 Q9HBH9|MNK2

Q9BUB5 | MNK1 Q9HBH9|MNK2

Q9BUB5 | MNK1 Q9HBH9|MNK2
1

1 MVQKKPAFLQGFHRSFKGQNPFELAFSIDQPDHGDSDFGIQCSARPDMPASQPTDIPDAK . : $:^{*}:^{*}:{ }^{*}:{ }^{*}{ }^{*}{ }^{*}$.

26 RRRKKKRRGRATDSLPGKFEDMYKLTSELLGEGAYAKVQGAVSLQNGKEYAVKIIEKQAG 85 61 KRGKKKKRGRATDSFSGRFEDVYQLQEDVLGEGAHARVQTCINLITSQEYAVKIIEKQPG 120

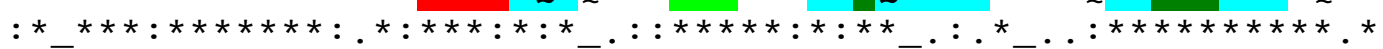

86 HSRSRVFREVETLYQCQGNKNILELIEFFEDDTRFYLVFEKLQGGSILAHIQKQKHFNER 145 121 HIRSRVFREVEMLYQCQGHRNVLELIEFFEEEDRFYLVFEKMRGGSILSHIHKRRHFNEL 180

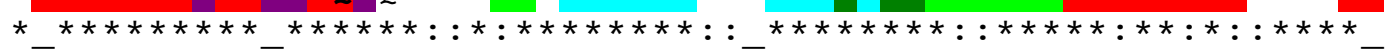

146 EASRVVRDVAAALDFLHTKDKVSLCHLGWSAMAPSGLTAAPTSLGSSDPPTSASQVAGTT 205 181 EASVVVQDVASALDFLHN $\ldots \ldots \ldots \ldots$

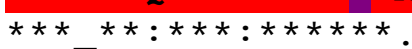

206 GIAHRDLKPENILCESPEKVSPVKICDFDLGSGMKLNNSCTPITTPELTTPCGSAEYMAP 265 200 GIAHRDLKPENILCEHPNQVSPVKICDFD GSGIKLNGDCSPISTPELLTPCGSAEYMAP 259

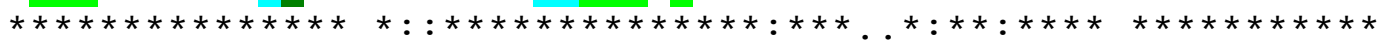

266 EVVEVFTDQATFYDKRCDLWSLGVVLYIMLSGYPPFVGHCGADCGWDRGEVCRVCQNKLF 325 260 EVVEAFSEEASIYDKRCDLWSLGVILYILLSGYPPFVGRCGSDCGWDRGEACPACQNMLF 319

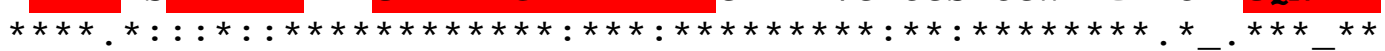

326 ESIQEGKYEFPDKDWAHISSEAKDLISKLLVRDAKQRLSAAQVLQHPWVQGQAPEKGLPT 385 320 ESIQEGKYEFPDKDWAHISCAAKDLISKLLVRDAKQRLSAAQVLQHPWVQGCAPENTLPT 379

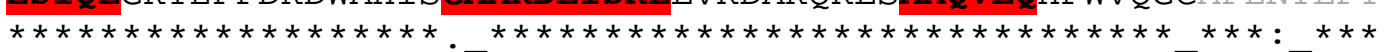

386 PQVLQRNSSTMDLTLFAAEAIALNRQLSQHEENELAEEPEALADGLCS - - - - - - MKLSPP 439 380 PMVLQRNSCAKDLTSFAAEAIAMNRQLAQHDEDLAEEEAAGQGQPVLVRATSRCLQLSPP 439

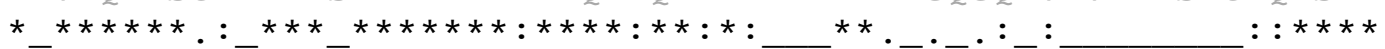

440 CKSRLARRRALAQAGRGEDRSPPTAL 405 440 SQSKLAQRRQRASLSSAPVVLVGDHA 465 


\section{X-ray crystal structure details}

\section{Protein expression and purification:}

MNK2 kinase domain (amino acids $72-385)^{1}$ was cloned into a pGEX-6P-1 vector with a modified thrombin protease site. The GST-thrombin site-Mnk2 kinase construct was transformed into BL21 Star (DE3) E. Coli bacterial strain and grown in LB media. The cells were grown to an $\mathrm{OD}_{600}=0.7$ and induced with $1 \mathrm{mM}$ IPTG and harvested after 6 hours at $25^{\circ} \mathrm{C}$.

The cells were lysed using buffer containing $10 \mathrm{mM} \mathrm{Na}_{2} \mathrm{HPO}_{4} \mathrm{pH} 7.4,150 \mathrm{mM} \mathrm{NaCl}, 1$ tablet of protease inhibitor, DNAse $(6.25 \mathrm{mg} / \mathrm{ml})$, lysozyme $(1.25 \mathrm{mg} / \mathrm{ml}), 5 \mathrm{mM} \beta$-mercaptoethanol and centrifuged. The GST tagged MNK2 kinase protein was purified from the supernatant using affinity chromatography on a Bio-Scale Mini Profinity GST cartridge using the Bio-Rad Profinia system. The GST tagged protein was incubated with thrombin in a 1:300 ratio (wt:wt, Thrombin:fusion protein) overnight at room temperature. One more GST affinity chromatography was performed to separate the cleaved tags from the protein. The protein was then purified by ion exchange chromatography HiTrapQ HP column using binding buffer (10 $\mathrm{mM}$ Tris $\mathrm{pH} 7.5,50 \mathrm{mM} \mathrm{NaCl}, 1 \mathrm{mM}$ DTT) and elution buffer $(10 \mathrm{mM}$ Tris $\mathrm{pH} 7.5,1 \mathrm{M} \mathrm{NaCl}$, $1 \mathrm{mM}$ DTT). Pure fractions of MNK2 protein was concentrated to $12 \mathrm{mg} / \mathrm{ml}$ and stored at $-80^{\circ} \mathrm{C}$.

\section{Crystallization and structure solution:}

Pure wild type MNK2 protein was crystallized using hanging drop vapor diffusion technique. $1 \mu \mathrm{l}$ of the protein was mixed with $1 \mu \mathrm{l}$ of the crystallization solution containing $23 \%$ polyacrylic acid 5100, 2\% 2-methyl-2,4-pentane diol, 100mM HEPES pH 7.7 at $20^{\circ} \mathrm{C}$. The apo-crystal obtained was soaked for 30 minutes in a reservoir solution containing $1 \mathrm{mM}$ of the ligand. The ligand soaked crystals were flash frozen in liquid nitrogen after cryo protecting them with $30 \%$ glycerol.

The dataset was collected using Rigaku MicroMaxTM 007 HF X-ray diffractometer. The dataset was indexed, integrated and scaled using D*Trek software. ${ }^{2}$ The structure of MNK2

\footnotetext{
${ }^{1}$ Jauch, R.; Jäkel, S.; Netter, C.; Schreiter, K.; Aicher, B.; Jäckle, H.; Wahl, M. C. Crystal Structures of the Mnk2 Kinase Domain Reveal an Inhibitory Conformation and a Zinc Binding Site. Structure 2005, 13, 1559-1568.

${ }^{2}$ Pflugrath J.W. The finer things in X-ray diffraction data collection. Acta Crystallogr. D Biol. Crystallogr. 1999, $55,1718-1725$.
} 
(PDB ID: 2AC3) was used as the search model for molecular replacement using PHENIX suite of programs. ${ }^{3}$ Refinement of the structure was done using Phenix.refine. ${ }^{4,5}$

SI Table 5. Data collection and refinement statistics*

\begin{tabular}{|l|c|}
\hline Resolution range & $28.28-2.90(3.00-2.90)$ \\
\hline Space group & P 3221 \\
\hline Unit cell & $10359(1002)$ \\
\hline Unique reflections & 2.0 \\
\hline Multiplicity & $98.52(99.21)$ \\
\hline Completeness (\%) & $6.5(1.5)$ \\
\hline Mean I/sigma(I) & 86.63 \\
\hline Wilson B-factor & $0.1(0.785)$ \\
\hline R-meas & $10333(1004)$ \\
\hline Reflections used in refinement & $483(28)$ \\
\hline Reflections used for R-free & $0.29(0.37)$ \\
\hline R-work & $0.35(0.50)$ \\
\hline R-free & 2136 \\
\hline Number of non-hydrogen \\
atoms
\end{tabular}

3 McCoy A.J.; Grosse-Kunstleve, R.W.; Adams, P.D.; Winn, M. D.; Storoni, L. C.; Read, R. J. Phaser Crystallographic Software. J. Appl. Cryst. 2007, 40, 658-674.

${ }^{4}$ Adams, P. D.; Gopal, K.; Grosse-Kunstleve, R. W.; Hung, L. W.; Ioerger, T. R.; McCoy, A. J.; Moriarty, N. W.; Pai, R. K.; Read, R. J.; Romo, T. D.; Sacchettini, J. C.; Sauter, N. K.; Storoni, L. C.; Terwilliger, T. C. Recent Developments in the PHENIX Software for Automated Crystallographic Structure Determination. $J$. Synchrotron Radiat. 2004, 11, 53-55.

${ }^{5}$ Adams, P. D.; Afonine, P. V.; Bunkóczi, G.; Chen, V. B.; Davis, I. W.; Echols, N.; Headd, J. J.; Hung, L.W.; Kapral, G. J.; Grosse-Kunstleve, R. W.; McCoy, A. J.; Moriarty, N. W.; Oeffner, R.; Read, R. J.; Richardson, D. C.; Richardson, J. S.; Terwilliger, T. C.; Zwart, P. H. PHENIX: a Comprehensive Python-based System for Macromolecular Structure Solution. Acta Crystallogr. D Biol. Crystallogr. 2010, 66, 213-221. 


\begin{tabular}{|l|c|}
\hline RMS(angles) & 1.17 \\
\hline Ramachandran favoured (\%) & 96.18 \\
\hline Ramachandran allowed (\%) & 3.82 \\
\hline Ramachandran outliers (\%) & 0.00 \\
\hline Rotamer outliers (\%) & 0.00 \\
\hline Clash score & 15.15 \\
\hline Average B-factor & 86.40 \\
\hline Macromolecules & 86.45 \\
\hline Ligands & 81.67 \\
\hline
\end{tabular}

* Statistics for the highest-resolution shell are shown in parentheses.

\section{Chemistry}

\section{General information}

All solvents and reagents were purchased from commercial source and used without further purification. ${ }^{1} \mathrm{H}$ NMR spectra were obtained using a Bruker Ultrashield 400 PLUS/R system, operating at $400 \mathrm{MHz} .{ }^{13} \mathrm{C}$ NMR spectra were acquired on Bruker Cryoprobe $400 \mathrm{MHz}$. The compounds' purities were $\geq 95 \%$ determined according to method A or B. Method A: VARIAN ProStar HPLC instrument using Acetonitrile/water (with $0.1 \%$ formic acid) as eluent, Phenomenex, Luna 5u, C18A (2) 100A, 150 x 4.60mm reverse phase column and mobile phase A: $0.1 \%$ Formic acid in water and mobile phase B: $0.1 \%$ Formic acid in Acetonitrile; run time: 10.5 mins; T/\%B: 0.0/3, 3.0/3, 7.50/50, 8.0/95, 10/95, 10.5/3; flow rate: $2.0 \mathrm{~mL} / \mathrm{min}$; wavelength: $254 \mathrm{~nm}$. Method B: Agilent UPLC using Acetonitrile/water (with $0.1 \%$ formic acid) as eluent; column: Phenomenex, Luna 5u, C18A (2) 100A, 50 x 4.60mm, reverse phase column; mobile phase A: $0.1 \%$ Formic acid in water; mobile phase B: $0.1 \%$ Formic acid in Acetonitrile; run time: $2.0 \mathrm{~min}$; T/\% B: 0.0/5, 1.8/95, 2.0/5; flow rate: $2.0 \mathrm{~mL} / \mathrm{min}$; wavelength: $254 \mathrm{~nm}$. HRMS spectra were acquired on Thermo Scientific Orbitrap Fusion mass spectrometer coupled with Advion TriVersa NanoMate (ESI); mass spectrometer setting: detector Orbitrap (high resolution), resolution 60000, mass accuracy $<3$ ppm.

\section{Preparation of compounds $51-52$}

Compounds 51 - 52 were prepared as shown on SI Scheme 1. Commercially available 4Bromobenzoic acid was converted into N-hydroxybenzamide II which was then esterified with 
2,2-Dimethylpropionic acid chloride leading to III. Condensation of III with 2 butyne or 2pentyne furnished the key intermediates IVa-c. Notably, the mixture of regioisomers IVb \& IVc was difficult to resolve and was carried forward to the next step. The following Suzuki coupling lead to the final compounds $\mathbf{5 1}$ and $\mathbf{5 2}$. Compound $\mathbf{5 2}$ was separated from regioisomer obtained from intermediate $\mathbf{I V b}$ - which in turn was not isolated.

\section{SI Scheme 1. Synthesis of compounds 51-52.}

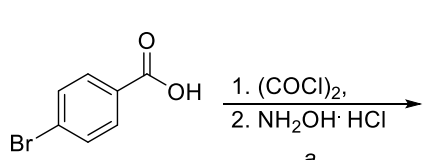

(I)

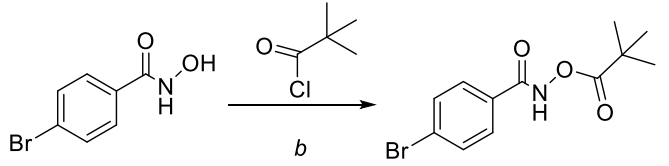

(II)
(III)

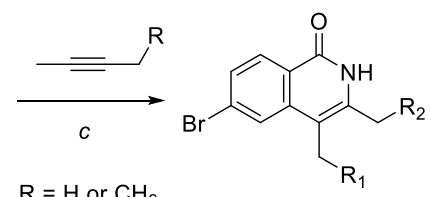

$\mathrm{R}=\mathrm{H}$ or $\mathrm{CH}_{3}$

(IVa) $\mathrm{R}_{1}=\mathrm{R}_{2}=\mathrm{H}$ (IVb) $\mathrm{R}_{1}=\mathrm{H}, \mathrm{R}_{2}=\mathrm{CH}_{3}$ (IVc) $\mathrm{R}_{1}=\mathrm{CH}_{3}, \mathrm{R}_{2}=\mathrm{H}$
(IV)<smiles>Cn1cc(B(O)c2cnn(C)c2)cn1</smiles><smiles>Cn1cc(-c2cncc(B3OC(C)(C)C(C)(C)O3)c2)cn1</smiles>

(VI)

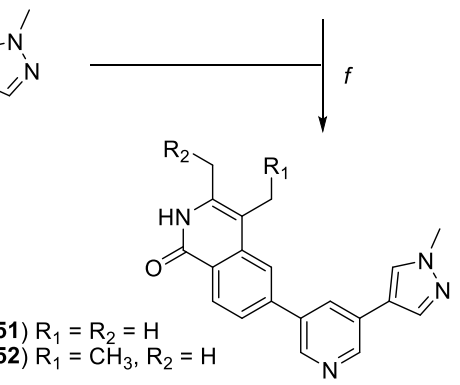

${ }^{a}$ Reagents and conditions: (a) 1. Oxalyl chloride (2 equiv.), $\mathrm{CH}_{2} \mathrm{Cl}_{2}, \mathrm{rt}, 1.5 \mathrm{~h} ; 2 . \mathrm{NH}_{2} \mathrm{OH} * \mathrm{HCl}$ (4 equiv.), $\mathrm{NaOH}$ (6 equiv.), THF / $\mathrm{H}_{2} \mathrm{O}$ (1/1), 3 h, rt; (b) Pivaloyl chloride (1.1 equiv.), TEA (5.0 eq), THF, rt, 2 h; (c) 2-Butyne (5 equiv.), carbonyl( $\eta-5$-cyclopentadienyl)diiodocobalt (III) (0.1 equiv.), Sodium acetate (1.0 eq), $\mathrm{CF}_{3} \mathrm{CH}_{2} \mathrm{OH}, \mathrm{rt}$, 2h; (d) N-methyl-pyrazole-4-boronic acid (1.1 equiv.), $\mathrm{Cs}_{2} \mathrm{CO}_{3}$ (3 equiv.), $\mathrm{Pd}\left(\mathrm{PPh}_{3}\right)_{4}$ (0.05 equiv.), 1, 4-dioxane, $\mathrm{H}_{2} \mathrm{O}, 100^{\circ} \mathrm{C}, 4 \mathrm{~h}$; (e) Pinacolatodiboron (1.5 equiv.), $\mathrm{NaOAc}$ ( 3 equiv.), $\mathrm{Pd}_{2} \mathrm{Cl}_{2}$ (dppf).DCM (0.05 equiv.), 1, 4dioxane, $140{ }^{\circ} \mathrm{C}, 2 \mathrm{~h}$, $\mu \mathrm{w}$; (f) VI (2 equiv.), $\mathrm{Cs}_{2} \mathrm{CO}_{3}$ (2 equiv.), $\mathrm{H}_{2} \mathrm{O}, 1,4-$ Dioxane, $\left.\mathrm{Pd}_{(} \mathrm{PPh}_{3}\right)_{2}(0.1$ equiv.), $16 \mathrm{~h}$, $80^{\circ} \mathrm{C}$.

\section{Representative procedures - synthesis of compound 51.}

\section{Step-1: Preparation of 4-bromo-N-hydroxybenzamide}

4-Bromobenzoic acid (2.6 g, 1 equiv.) was treated with Oxalyl chloride (2.22mL, $26 \mathrm{mmol}, 2$ equiv.) in $\mathrm{CH}_{2} \mathrm{Cl}_{2}(10 \mathrm{ml})$ at room temperature for $1.5 \mathrm{~h}$. Volatiles were evaporated, residue diluted with 1:1 mixture of THF and water and Hydroxyloamine hydrochloride $(3.34 \mathrm{~g}, 52.3$ mmol, 4 equiv.) was added, followed by $\mathrm{NaOH}$ (3.12 g, $78.4 \mathrm{mmol}, 6$ equiv.) and the reaction mixture was stirred for $3 \mathrm{~h}$ at room temperature. The reaction mixture was then cooled to room temperature, poured onto water $(20 \mathrm{~mL})$ and extracted with Ethyl Acetate $(3 \mathrm{x} 50 \mathrm{~mL})$. The organic layer was separated, washed with brine, dried over $\mathrm{Na}_{2} \mathrm{SO}_{4}$ and concentrated in vacuo. The resulting residue was purified by flash chromatography on silica gel eluting with a gradient of Ethyl Acetate in Hexane to yield intermediate II (2.3 g). (LCMS: 99\%)

\section{Step-2: Preparation of 4-bromo-N-(pivaloyloxy)benzamide}

Intermediate II (500 mg, $2.3 \mathrm{mmol}, 1.0$ equiv.) was treated with Pivaloyl chloride ( $0.3 \mathrm{~mL}, 2.6$ mmol, 1.1 equiv. $)$ TEA $(1.6 \mathrm{~mL}, 11.6 \mathrm{mmol}, 5$ equiv. $)$ in THF $(10 \mathrm{~mL})$ at room temperature 
for $2 \mathrm{~h}$. The reaction mixture was poured onto water $(10 \mathrm{~mL})$ and extracted using Ethyl Acetate $(2 \times 20 \mathrm{~mL})$. The organic layer was separated, washed with brine, dried over $\mathrm{Na}_{2} \mathrm{SO}_{4}$ and concentrated in vacuo to obtain crude compound III (550mg). (LCMS: 66\%)

\section{Step-3: Preparation of 6-bromo-3,4-dimethylisoquinolin-1(2H)-one}

Solution of intermediate III (550 mg, $1.8 \mathrm{mmol}, 1$ equiv.) in $\mathrm{CF}_{3} \mathrm{CH}_{2} \mathrm{OH}$ (10 mL) was treated with 2-Butyne (109 mg, $89.2 \mathrm{mmol}, 5$ equiv.), carbonyl( $\eta-5$-cyclopentadienyl)diiodocobalt (III) (113 mg, $0.18 \mathrm{mmol}, 0.1$ equiv.) and Sodium acetate ( $150 \mathrm{mg}, 1.8 \mathrm{mmol}, 1.0$ equiv.) at room temperature. The reaction was stirred for $2 \mathrm{~h}$ at room temperature and monitored by TLC. Upon completion, the reaction mixture was cooled and poured onto water $(5 \mathrm{~mL})$ and extracted with Ethyl Acetate $(2 \times 10 \mathrm{~mL})$. Organic layer was separated and washed with brine ( $5 \mathrm{~mL}$ ), dried over $\mathrm{Na}_{2} \mathrm{SO}_{4}$ and concentrated in vacuo. The resulting residue was purified via flash chromatography on silica gel eluting with a gradient of Ethyl Acetate in Hexane to yield intermediate IV a (270 mg; LCMS: 84\%)

\section{Step-4: Preparation of 3-bromo-5-(1-methyl-1H-pyrazol-4-yl)pyridine}

To the solution of 3-Bromo-5-iodopyridine (1.2 g, 1 equiv.) in 1, 4-dioxane (20 mL) and water ( $5 \mathrm{~mL}$ ) was added $\mathrm{Cs}_{2} \mathrm{CO}_{3}$ (3.4 g, 23 equiv.), N-methyl-pyrazole-4-boronic acid (0.488 g, 1.1 equiv.) and the mixture was degassed with Nitrogen gas for 5 mins. Then $\mathrm{Pd}\left(\mathrm{PPh}_{3}\right)_{4}(0.244 \mathrm{~g}$, 0.05 equiv.) was added and the reaction mixture was heated to $100^{\circ} \mathrm{C}$ for $4 \mathrm{~h}$. On completion, the cooled reaction mixture and was poured onto water $(50 \mathrm{~mL})$ and extracted with Ethyl acetate $\left(30 \mathrm{~mL}\right.$ x 3). Organic layer was washed with brine, dried over $\mathrm{Na}_{2} \mathrm{SO}_{4}$ and evaporated in vacuo. The crude product was purified by chromatography on silica gel (60-120 mesh) eluting with $10 \%$ Ethyl Acetate in Hexane as eluent to yield intermediate $\mathbf{V}$ as a yellow semisolid (0.950 g; LCMS: $71 \%$; M/z=238).

\section{Step-5: Preparation of 3-(1-methyl-1H-pyrazol-4-yl)-5-(4,4,5,5-tetramethyl-1,3,2- dioxaborolan-2-yl)pyridine}

To the solution of intermediate $\mathbf{V}(1.0 \mathrm{~g}, 1.0$ equiv. $)$ in 1, 4-dioxane $(20 \mathrm{~mL})$ was added $\mathrm{NaOAc}$ (1.04 g, 3.0 equiv.), Pinacolatodiboron (1.60 g, 1.5 equiv.) and the mixture was degassed with Nitrogen gas for 5 mins. Then $\mathrm{Pd}_{2} \mathrm{Cl}_{2}$ (dppf).DCM ( $0.172 \mathrm{~g}, 0.049$ equiv.) was added and the reaction mixture was heated at $140^{\circ} \mathrm{C}$ for $2 \mathrm{~h}$ in microwave reactor. The reaction mixture was then cooled, poured onto water $(50 \mathrm{~mL})$ and extracted with Ethyl Acetate $(30 \mathrm{~mL} \times 3)$. The organic layer was dried over $\mathrm{Na}_{2} \mathrm{SO}_{4}$, evaporated in vacuo to get intermediate $\mathrm{VI}$ as a brown solid (0.80 g).

\section{Step-6: Preparation of 3,4-dimethyl-6-(5-(1-methyl-1H-pyrazol-4-yl)pyridin-3- yl)isoquinolin-1(2H)-one}

To the solution of intermediate IVa $(50 \mathrm{mg}, 0.20 \mathrm{mmol}, 1.0$ equiv.), intermediate VI (120 mg, $0.40 \mathrm{mmol}, 2.0$ equiv.) and $\mathrm{Cs}_{2} \mathrm{CO}_{3}(128 \mathrm{mg}, 0.4 \mathrm{mmol}, 2.0$ equiv.) in water $(0.7 \mathrm{~mL})$ was added solution of $\mathrm{Pd}\left(\mathrm{PPh}_{3}\right)_{2}(12 \mathrm{mg}, 0.01 \mathrm{mmol}, 0.1$ equiv. $)$ in dioxane $(2.8 \mathrm{~mL})$ and the mixture 
was degassed by bubbling Nitrogen through for 5 minutes. Reaction vial was then capped and the mixture stirred for $16 \mathrm{~h}$ at $80{ }^{\circ} \mathrm{C}$. The reaction mixture was then cooled to room temperature, poured onto water $(10 \mathrm{~mL})$ and extracted with ethyl acetate $(2 \times 20 \mathrm{~mL})$. The organic layer was separated and washed with brine, dried over $\mathrm{Na}_{2} \mathrm{SO}_{4}$ and concentrated in vacuo. The resulting residue was purified by flash chromatography on silica gel eluting with $50 \%$ Ethyl Acetate in Hexane to yield compound $\mathbf{5 1}$ (5 mg) 3,4-dimethyl-7-[5-(1-methyl-1H-pyrazol-4-yl)pyridin-3yl]-1,2,3,4-tetrahydroisoquinolin-1-one.

${ }^{1} \mathrm{H}$ NMR (400 MHz, DMSO- $\left.d_{6}\right) \delta(\mathrm{ppm}): \delta 11.23(\mathrm{~s}, 1 \mathrm{H}), 8.91(\mathrm{~s}, 1 \mathrm{H}), 8.85(\mathrm{~s}, 1 \mathrm{H}), 8.40(\mathrm{~d}, J$ $=16.8 \mathrm{~Hz}, 2 \mathrm{H}), 8.31(\mathrm{~d}, J=8.2 \mathrm{~Hz}, 1 \mathrm{H}), 8.14(\mathrm{~s}, 1 \mathrm{H}), 7.99(\mathrm{~s}, 1 \mathrm{H}), 7.85(\mathrm{~d}, J=8.4 \mathrm{~Hz}, 1 \mathrm{H})$, $3.92(\mathrm{~s}, 3 \mathrm{H}), 3.52(\mathrm{~s}, 1 \mathrm{H}), 2.30(\mathrm{~s}, 6 \mathrm{H}), 1.24(\mathrm{~s}, 1 \mathrm{H})$; LCMS (ESI) m/z calcd for $\mathrm{C}_{20} \mathrm{H}_{20} \mathrm{~N}_{4} \mathrm{O}_{2}$ $[\mathrm{M}+\mathrm{H}]^{+}=330.4$, found 330.3 ; off-white solid; purity $96 \%$.

4-Ethyl-3-methyl-7-[5-(1-methyl-1H-pyrazol-4-yl)pyridin-3-yl]-1,2,3,4-etrahydroisoquinolin1-one (52)

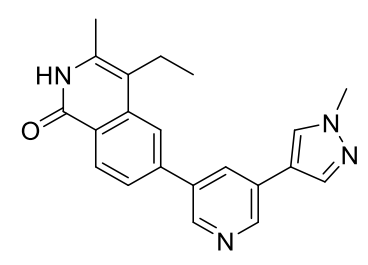

The title compound was obtained analogically to cmpd $\mathbf{5 1}$ using 2-pentyne instead on 2-butyne in step 3. The regioisomer of $\mathbf{5 2}$ was separated through flash chromatography on silica gel (not recovered).

${ }^{1} \mathrm{H}$ NMR (400 MHz, DMSO- $\left.d_{6}\right) \delta$ ppm: $11.25(\mathrm{~s}, 1 \mathrm{H}), 8.91(\mathrm{~d}, J=2.0 \mathrm{~Hz}, 1 \mathrm{H}), 8.83(\mathrm{~d}, J=$ $2.2 \mathrm{~Hz}, 1 \mathrm{H}), 8.42(\mathrm{~s}, 1 \mathrm{H}), 8.38-8.29(\mathrm{~m}, 2 \mathrm{H}), 8.14(\mathrm{~s}, 1 \mathrm{H}), 8.00(\mathrm{~d}, J=1.6 \mathrm{~Hz}, 1 \mathrm{H}), 7.84$ $(\mathrm{dd}, J=8.3,1.6 \mathrm{~Hz}, 1 \mathrm{H}), 3.93(\mathrm{~s}, 3 \mathrm{H}), 2.83(\mathrm{~d}, J=7.5 \mathrm{~Hz}, 1 \mathrm{H}), 2.30(\mathrm{~s}, 3 \mathrm{H}), 1.15(\mathrm{t}, J=7.4$ $\mathrm{Hz}, 3 \mathrm{H}$ ); LCMS (ESI) $\mathrm{m} / \mathrm{z}$ calcd for $\mathrm{C}_{21} \mathrm{H}_{21} \mathrm{~N}_{4} \mathrm{O}[\mathrm{M}+\mathrm{H}]^{+}=345.42$, found 345.2; off-white solid; purity $96 \%$. 


\section{HPLC spectrograms of advanced compounds}

\section{Compound 37}

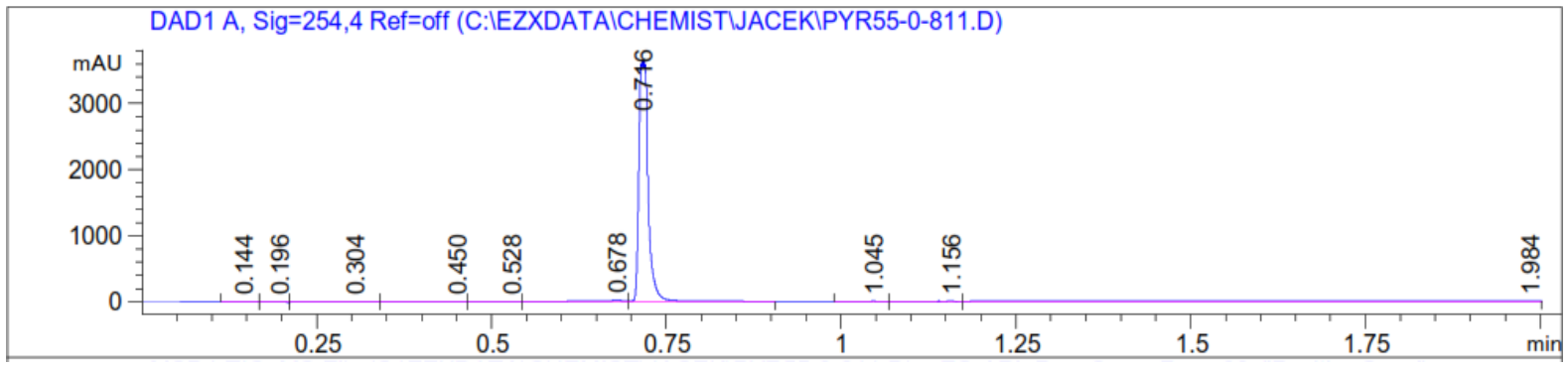

\section{Compound 38}

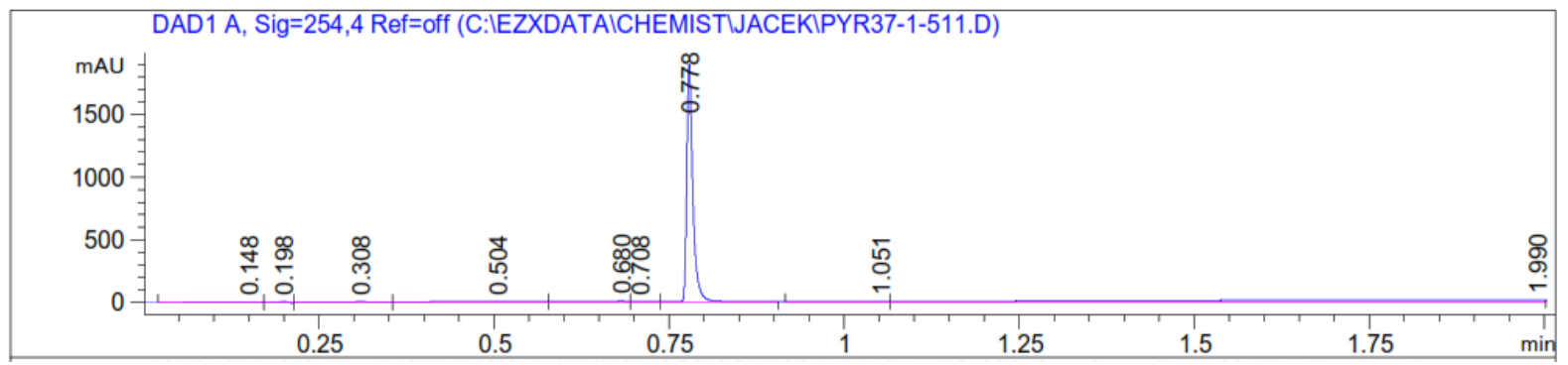

\section{Compound 42}

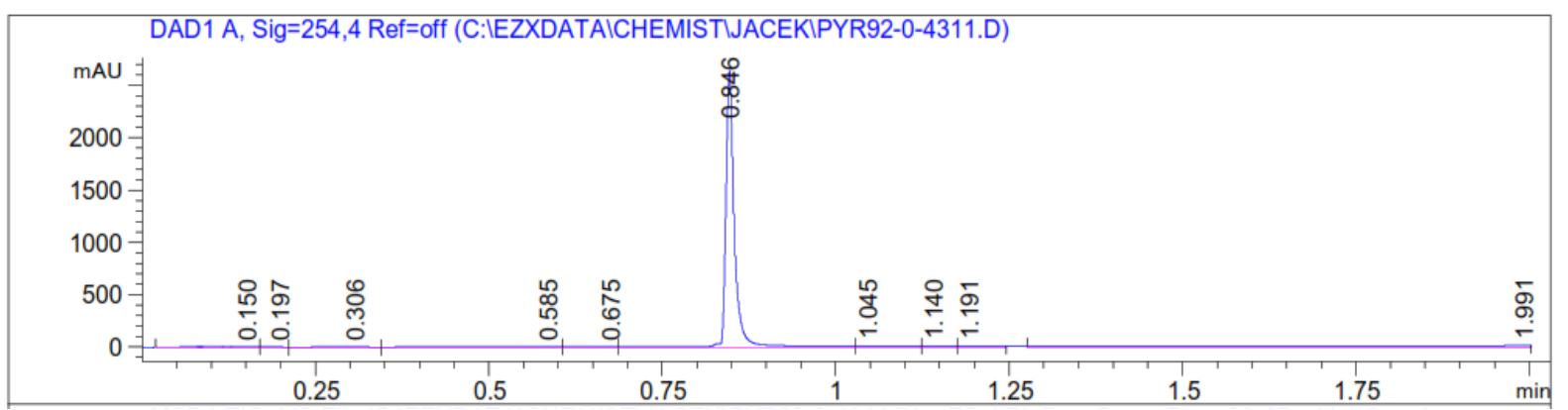

\section{Compound 43}

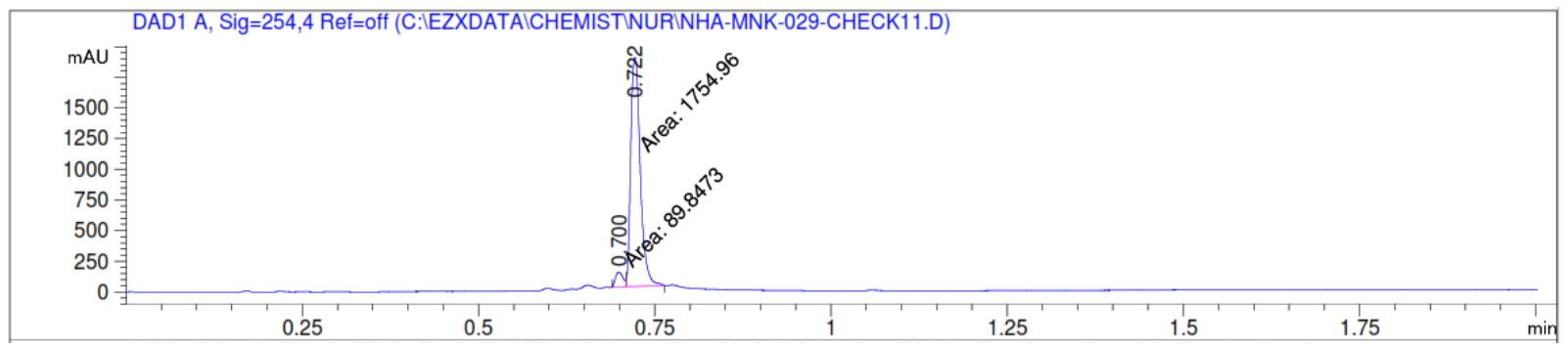




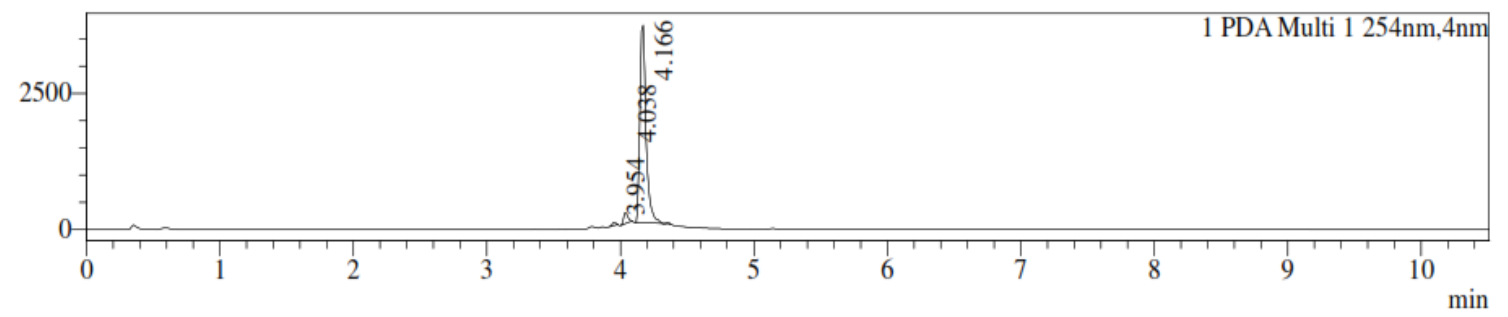

Peak Table

PDACh1 $254 \mathrm{~nm}$
\begin{tabular}{r|r|r|r|r|r|}
\hline Index\# & Name & Ret. Time & Area\% & Peak Start & Peak End \\
\hline 1 & & 3.954 & 0.94 & 3.925 & 3.979 \\
\hline 2 & & 4.038 & 3.82 & 4.011 & 4.085 \\
\hline 3 & & 4.166 & 95.24 & 4.117 & 4.373 \\
\hline Total & & & 100.00 & & \\
\hline
\end{tabular}

\section{Compound 44}

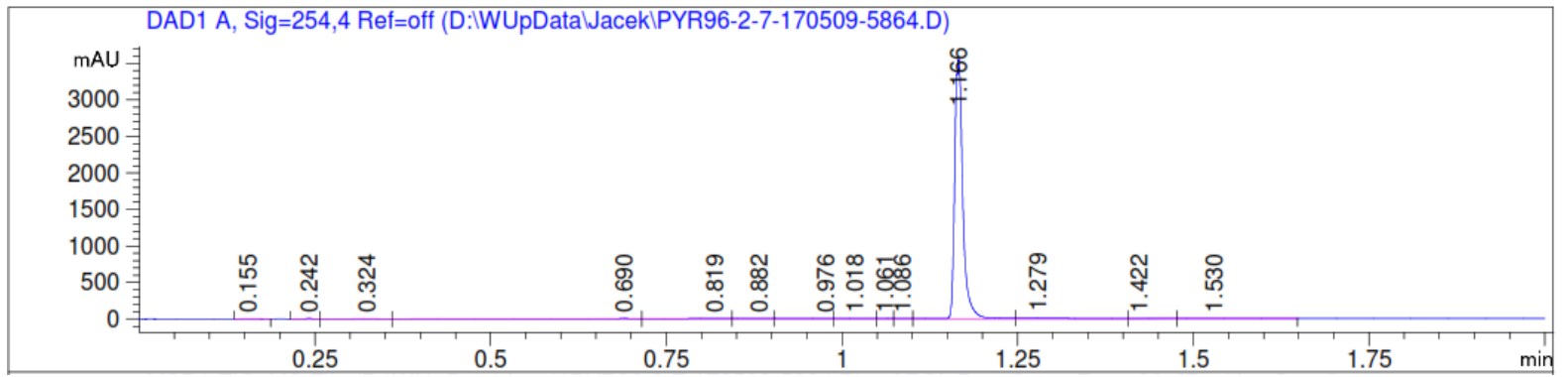

\section{Compound 45}

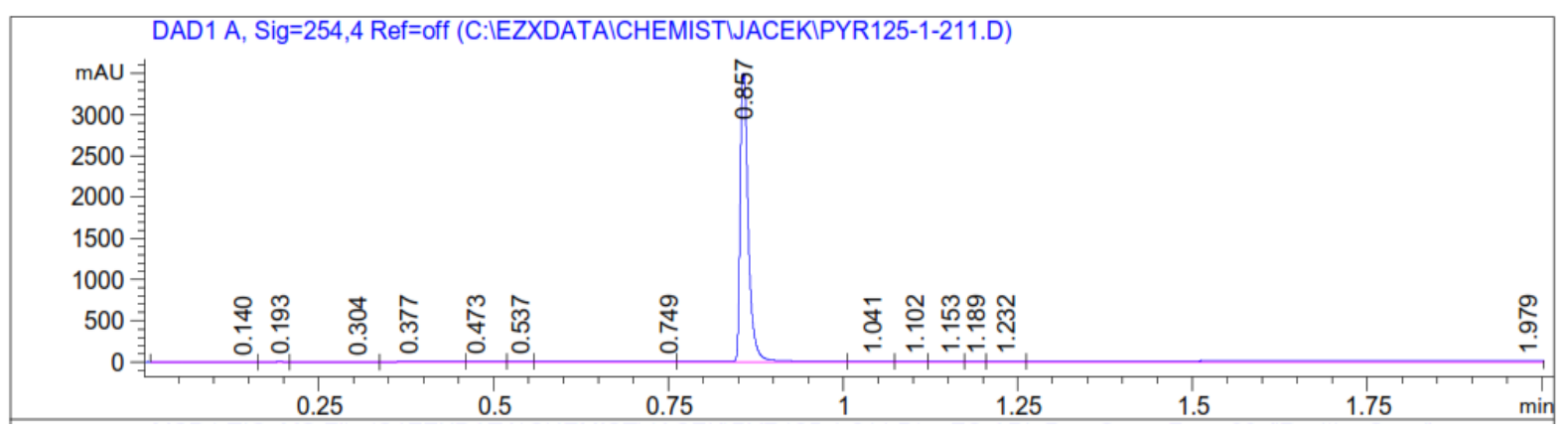

\section{Compound 46}

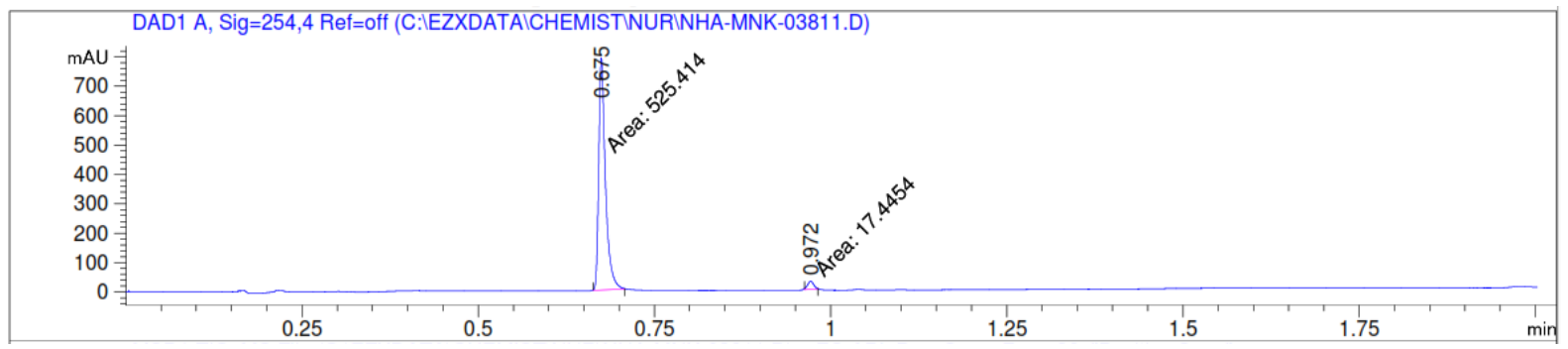




\section{Compound 47}

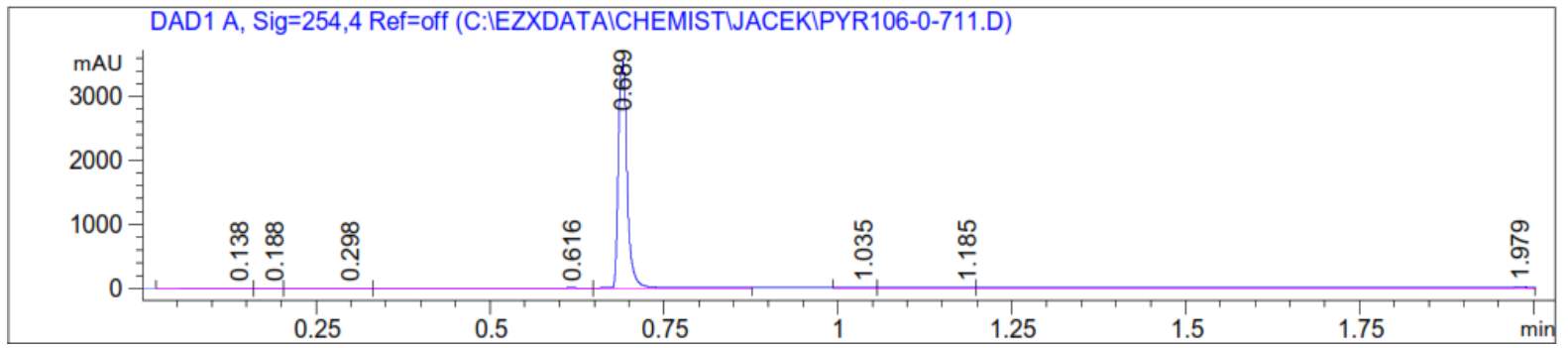

\section{Compound 48}

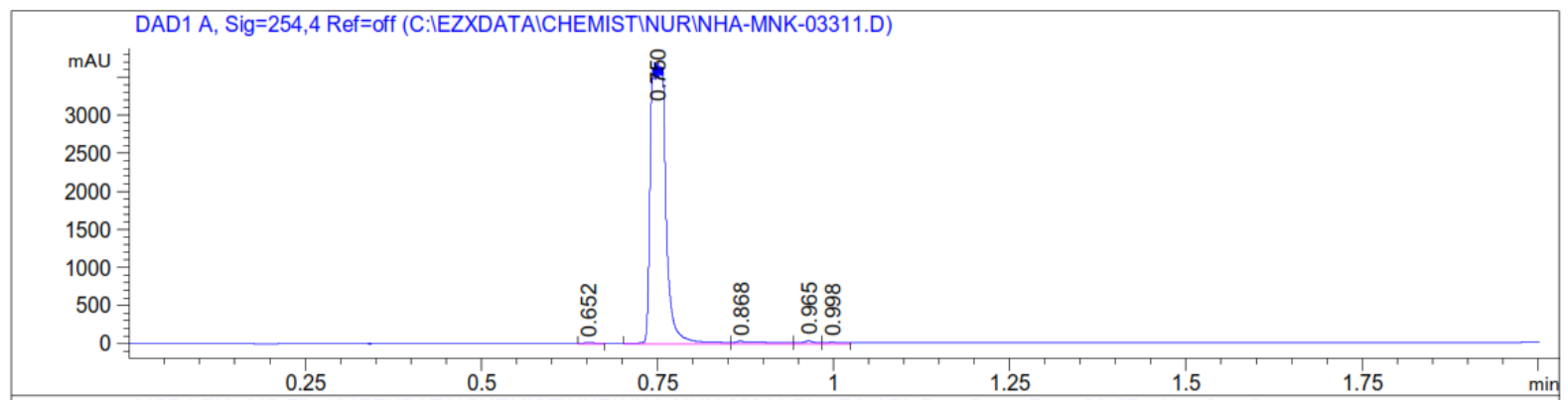

\section{Compound 49}

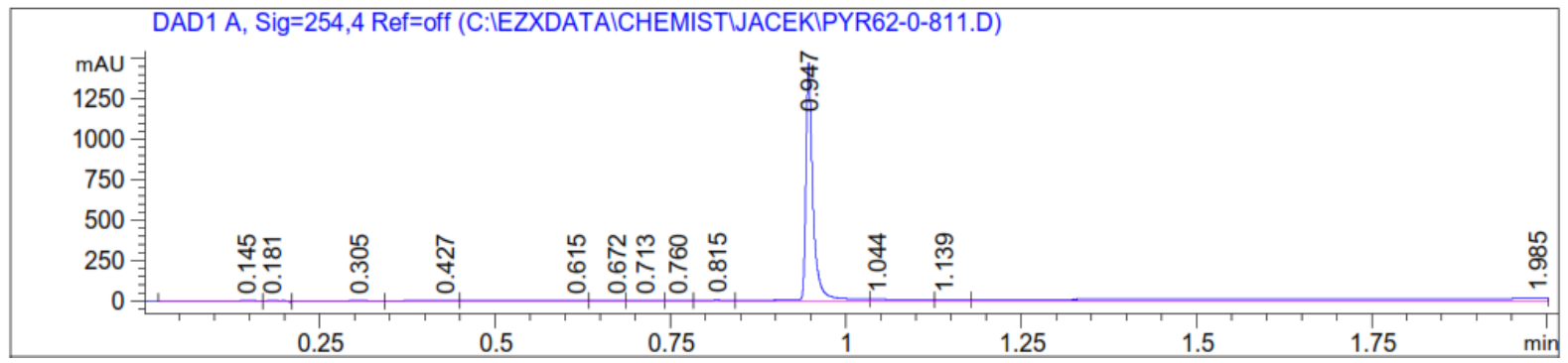

